\title{
Diagnosis of Chagas disease: what has been achieved? What remains to be done with regard to diagnosis and follow up studies?
}

\author{
Yara M Gomes ${ }^{1 /+}$, Virginia MB Lorena ${ }^{1}$, Alejandro O Luquetti \\ 'Laboratório de Imunoparasitologia, Departamento de Imunologia, Centro de Pesquisas Aggeu Magalhães-Fiocruz, Av. Moraes Rego s/n, \\ Cidade Universitária, 50670-420 Recife, PE, Brasil ${ }^{2}$ Hospital das Clínicas, Universidade Federal de Goiás, Goiânia, GO, Brasil
}

In the acute phase and in the chronic forms of Chagas disease, the etiological diagnosis may be performed by detection of the parasite using direct or indirect parasitological methods and by the presence of antibodies in the serum by way of serological tests. Several techniques are easily available, ranging from the simplest wet smear preparation to immuno-enzymatic assays with recombinant antigens that will meet most diagnostic needs. Other tests under evaluation include a molecular test using polymerase chain reaction, which has shown promising results and may be used as a confirmatory test both in the acute and chronic phases of the disease. Better rapid tests are needed for diagnosis, some of which are already under evaluation. Additionally, there is a need for tools that can identify patients cured shortly after specific treatment. Other needs include a marker for prognosis and early diagnosis of congenital transmission.

Key words: Chagas disease - Trypanosoma cruzi - etiological diagnosis

On the 100th anniversary of the discovery of Chagas disease, etiological diagnosis of infection has evidently improved, although methods for parasitological diagnosis, such as xenodiagnosis-(XD) (Brumpt 1914) and serological diagnosis (Guerreiro \& Machado 1913), became available not long after Chagas' 1909 publication and are still being used in some laboratories. As described by Luquetti (1999), improvements in diagnosis can be seen to have occurred during a number of key periods: during the first period, from discovery until 1960, diagnosis was performed using XD for parasitological research and using complement fixation reaction (CFR) for serological diagnosis of the chronic phase. During a second period, from 1960-1975, major progress was made. For diagnosis of the acute phase, a major step forward was the introduction of Strout's hemoflagellate method (1962). It should be pointed out that prior to the development of this approach, the method used until for parasitological diagnosis of this phase was that first performed by Chagas (the wet blood smear and animal inoculation). For the chronic phase, during this period, parasitological diagnosis included hemoculture (Chiari \& Brenner 1966). Serological diagnosis was firmly established with the standardization of the CFR [Almeida \& Fife 1976, the introduction of indirect haemaglutination (IHA)] (Cerisola et al. 1962), IgG-IIF indirect immunofluorescence

Financial support: Biomanguinhos-Fiocruz (CC 09/2007), PDTSP-Fiocruz (PCL04), CNPq (YMG 306427/2006-0), VMBL (143023/2006-3). + Corresponding author: yara@cpqam.fiocruz.br

Received 26 March 2009

Accepted 3 June 2009
(Camargo 1966) and the immunoenzymatic ELISA test (Voller et al. 1975). The third period, from 1975 until the present day, has been characterised by the use of high technology in parasitological and serological approaches. Parasitological diagnosis was further improved with the introduction of polymerase chain reaction (PCR) (Moser et al. 1989, Sturn et al. 1989, Britto et al. 1995) and quantitative real time PCR (Cummings \& Tarleton 2003, Virreira et al. 2006, Piron et al. 2007, Duffy et al. 2009). Serological diagnosis stopped using the crude antigens that were previously used and began to include a number of purified antigens, such as GP90 kDa, GP72 $\mathrm{kDa}, \mathrm{GP} 25 \mathrm{kDa}, \mathrm{GP} 55 \mathrm{kDa}$ and shortly thereafter, recombinant antigens and synthetic peptides, which were evaluated by way of multicentre trials (Moncayo \& Luquetti 1990, Levin et al. 1991, Umezawa et al. 1999).

Recently, the Brazilian Ministry of Health (MS) held a meeting with Brazilian scientists working with Chagas disease in order to standardise diagnosis, treatment, prevention and control strategies and establish a Brazilian consensus with regard to Chagas disease (MS 2005). In light of this consensus, we discuss here what has so far been achieved and what remains to be done with regard to diagnosis and follow up studies of Chagas disease.

What methods are currently available for diagnosis during the acute and chronic phases?

In the acute phase of Chagas disease, parasites circulate in the bloodstream. During this phase, laboratory diagnosis is based on observation of the parasite in the infected blood of individuals using a parasitological fresh-blood test, as well as smear and thick drop blood tests. The direct test using fresh blood is more sensitive than the stained smear test and should be the method of choice during the acute phase of infection. If these tests are negative, concentration tests must be carried out. 
Concentration tests (microhematocrit or Strout test) have a sensitivity of $80-90 \%$ (Luquetti \& Rassi 2000) and are recommended in the case of patients strongly suspected of having acute Chagas disease and returning negative results for the direct fresh-blood exam. In symptomatic cases lasting more than 30 days, for direct negative tests, concentration tests should be the first choice, as parasitaemia begins to decline at this stage (MS 2005).

In suspected cases of congenital transmission, it is important to test for infection of the mother. If this is confirmed, a parasitological test should be performed on the newborn. If this test result is positive, the child should immediately undergo etiological treatment, in view of the high rate of cure in this phase. Children born to mothers with Chagas disease who have tested negative for the parasite or who have not been tested should return for examination within 6-9 months, in order to perform serological tests looking for specific IgG antibodies against Trypanosoma cruzi. If serology results are negative, vertical transmission can be ruled out. Fig. 1 shows the flowchart for diagnosis of cases at risk of vertical transmission. Owing to the high number of false-negatives in congenital transmission, testing for anti-T. cruzi class IgM and IgA antibodies is not recommended (MS 2005).

The chronic phase of the disease, which follows the resolution of the acute infection, is characterised by levels of circulating parasites far below the threshold for microscopic detection and also by the appearance of $\operatorname{IgG}$ antibodies directed against the antigens of T. cruzi. Diagnosis in this phase is based primarily on conventional serology (CS), IIF, IHA, enzyme-linked immunosorbent assay-ELISA) or indirect parasitological methods (XD and haemoculture). Although specific, these indirect parasitological methods have low sensitivity (20-50\%) (WHO 1991, Gomes 1997, Luquetti \& Rassi 2000). In view of the low sensitivity of parasitological tests, diagnosis during the chronic phase is at present essentially serological. Accurate diagnosis at this stage is important for the individual and also for epidemiological reasons, because transmission by way of blood transfusion and organ transplantation occurs in endemic and non-endemic countries (Schmunis 1991, 2007). Recently, Souza et al. (2008) described a case of acute Chagas disease with severe cardiac involvement following an orthotopic liver transplant from a cadaver donor. Both donor and recipient tested serologically negative for $T$. cruzi prior to the procedure. This finding shows the possibility of false-negative results and highlights the need for more accurate diagnostic criteria, which should include not only serological tests, but also careful consideration of the epidemiological background of Chagas disease and an active search for the parasite using PCR methods as suggested by Gomes et al. (1999).

According to the MS (2005), diagnosis during the chronic phase of Chagas disease should be carried out using a test with high sensitivity (ELISA with total antigen or semi-purified fractions of the parasite, IIF or IHA) in combination with another parallel test with high specificity (ELISA, using T. cruzi-specific, recombinant antigens). If the results do not concur, the diagnosis is deemed inconclusive. In such cases, the samples must be retested using the same methods (Fig. 2). Because of the possibility of inconclusive results, the MS (2005) recommends that samples with persistent inconclusive results (3\% in a routine laboratory) be sent to referral laboratories, where they will be tested using other serological tests and more complex methods, such as PCR and western blot.

\section{What still needs to be done regarding diagnosis?}

The World Health Organization (WHO) has long emphasised the need to employ defined antigens as a way of improving the serodiagnosis of Chagas disease. Several research groups have therefore used recombinant/synthetic and biochemically purified antigens (Affranchino et al. 1989, Goldenberg et al. 1991, Krieger et al. 1992, Umezawa et al. 1999, Franco da Silveira et al. 2001). In order to be useful, these antigens must meet several criteria: (i) they should be present in $T$. cruzi isolates from different endemic areas, and absent from other infectious disease agents; (ii) they should be highly immunogenic in populations with different genetic backgrounds, irrespective of the clinical phase of Chagas disease and (iii) they should be stable and easily amenable to qualitycontrol tests, to guarantee reproducibility (Zingales et al. 1990, Stolf 1992).

An immunoblot assay using trypomastigote excreted-secreted antigens (TESA) for the Y strain of T. cruzi has been proposed as a sensitive and specific diagnostic assay (TESA-blot) in cases of suspected acute or congenital T. cruzi infection and as a general confirmatory test for conventional Chagas disease serology. The TESA-blot showed that a $150-160 \mathrm{kDa}$ band was recognised in the serum of $100 \%$ of chronic Chagas disease patients and did not react with the serum of patients with leishmaniasis (caused by organisms closely related to $T$. cruzi) (Umezawa et al. 1996). The TESA-blot was also evaluated by Nakazawa et al. (2001) using TESA from $T$. cruzi strains of different biodemes (WSL, Colombiana and $12 \mathrm{SF}$ ). A 150-170 $\mathrm{kDa}$ polypeptide was recognised in $100 \%$ of chronic Chagas disease patients tested (with cardiac, asymptomatic, digestive and mixed forms). Cross-reactions with visceral and cutaneous leishmaniasis serum were observed in the case of some polypeptides below $150 \mathrm{kDa}$ and no reaction was observed with normal human control serum. However, this assay is of no use in monitoring cure, since it does not allow for assessment of serological titre decay (Matsumoto et al. 2002). Furthermore, the western blot format is not very appropriate for testing a large number of samples. For this reason, the ELISA format is more convenient, as it is simple, easy to perform and amenable to automation. Nakazawa et al. (2001) thus developed and evaluated an ELISA using TESA-ELISA by analyzing 124 consensus samples and 204 samples of serum from individuals not infected with Chagas disease. Although the TESAELISA exhibited high sensitivity (100\%; CI 95\%: 96.3$100 \%$ ) and low specificity (96\%; CI 95\%: 92.5-97.9\%), cross-reactions were observed with cutaneous and vis- 
ceral leishmaniasis. The cross-reactivity observed may be due to a reaction to polypeptides below $150 \mathrm{kDa}$, as shown in the results obtained by Umezawa et al. (2001). To verify this hypothesis, the 150-170 kDa band from the Y strain of T. cruzi (Tc $15-170 \mathrm{kDa}$ ) was isolated by way of preparative electrophoresis and the fraction obtained. Tc 150-170 kDa was evaluated by means of TESA-ELISA, using serum from patients with Chagas disease, non-infected individuals and patients with cutaneous and visceral leishmaniasis. Sensitivity and specificity were $100 \%$ (Nakazawa et al. 2001).

On the other hand, a number of T. cruzi genes have been cloned and some recombinant antigens have been tested for use in diagnosis. Even though the majority of these are tested and used in research with satisfactory results, they have not been included in kits for technical and economic reasons (Franco da Silveira et al. 2001). Two recombinant antigens, cytoplasmic repetitive antigen (CRA) and flagellar repetitive antigen (FRA) (Lafaille et al. 1989), have been deemed useful for diagnostic purposes, according to a multicentre study carried out by the WHO (Almeida et al. 1990, Moncayo \& Luquetti 1990, Paranhos et al. 1990, Krieger et al. 1992, Carvalho et al. 1993). A kit for diagnosis of chronic Chagas disease called EIE-Recombinante-ChagasBiomanguinhos $^{\circledR}$ (Rec-ELISA), which uses these antigens in combination (CRA + FRA), has been developed and produced by Biomanguinhos, at the Oswaldo Cruz Foundation (Fiocruz), in Rio de Janeiro, Brazil. This kit is based on an enzyme immunoassay and direct ELISA and has been evaluated for diagnosis of T. cruzi infection (Gomes et al. 2001) and as a follow-up test for monitoring chemotherapy (Silva et al. 2002), with excellent results. The Rec-ELISA was also compared with the conventional ELISA(Con-ELISA) and IHA, with a view to minimizing the number of inconclusive results. For this, serum samples from patients with Chagas disease (112), from individuals not infected with Chagas (143) and from patients with other diseases (32) were tested using three assays: Rec-ELISA, Con-ELISA and IHA. When the data were evaluated by matching the Rec-ELISA and IHA test, 52 inconclusive results were obtained. When Rec-ELISA and Con-ELISA were matched, only four inconclusive results were observed, indicating that the use of two enzyme immunoassays with different antigen preparations provides a secure test combination for diagnosis of Chagas disease and blood-bank screening (Gadelha et al. 2003). The EIE-Rec kit presents a number of other advantages. First, it makes use of specific T. cruzi recombinant antigens, thereby avoiding falsepositive reactions. Second, the direct ELISA procedure increases the sensitivity of the method, thereby allowing for the evaluation of low titre serum samples and corroborating its specificity. Finally, the use of undiluted serum samples reduces the possibility of error arising during manipulation, as the only equipment it requires is an ELISA reader (Gomes et al. 2001).

Recombinant antigens have been employed in rapid tests with promising results (Roddy et al. 2008, Verani et al. 2009).

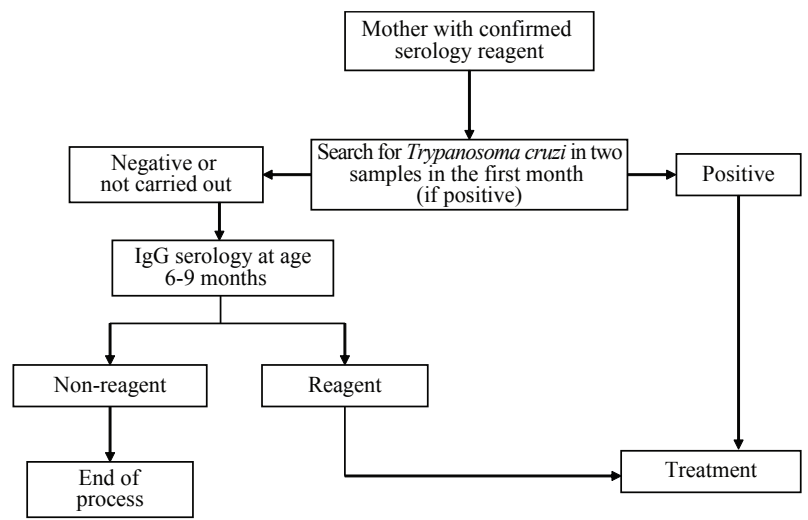

Fig. 1: flow chart evaluating vertical transmission of T. cruzi (MS 2005).

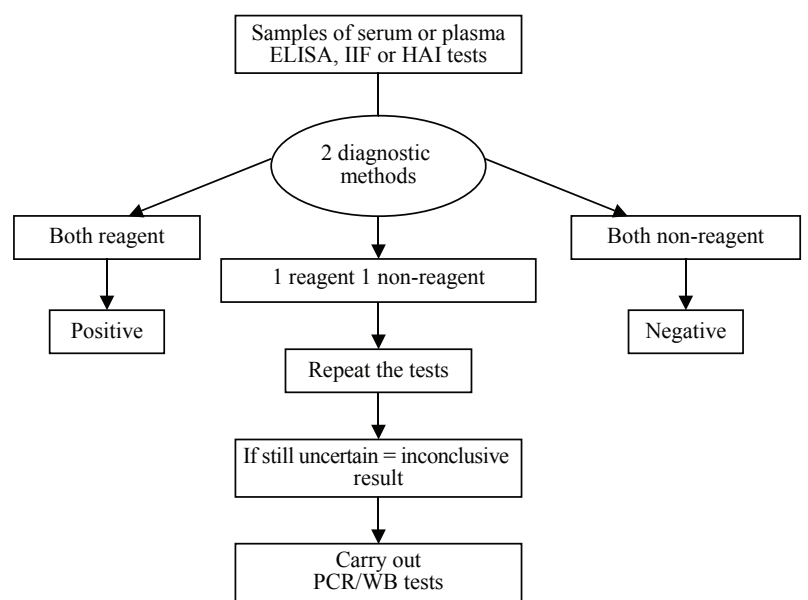

Fig. 2: flow chart of serological diagnosis for the detection Trypanosoma cruzi infection (MS 2005). ELISA: enzyme-linked immunosorbent assay; IIF: indirect immunofluorescence; HAI: indirect haemaglutination; PCR: polymerase chain reaction; WB: western blot.

\section{What remains to be done with regard to follow-up studies?}

Treatment of patients in the acute phase of the disease with Benznidazole and Nifurtimox is capable of preventing a fatal outcome and has a high rate of cure. Cure at this phase results in CS becoming completely and consistently negative after a period of around two years. However, in the chronic phase, negative sero-conversion is slow, taking years to complete and requiring a long follow-up to prove that the disease has been cured (Cançado 1999). The effectiveness of the treatment is evaluated using parasitological $\mathrm{HC}$ or XD tests and a CS test. The complement-mediated lysis test (CoML) (Krettli \& Brener 1982), which detects lytic antibodies against live trypomastigotes, has been linked to the presence of active infection and is also used for this purpose.

Following parasitological and serological tests, treated patients are classified as cured patients (CP), when parasitological, CS and CoML tests are negative, dis- 
sociated patients (DP), when parasitological and CoML tests are negative but remain positive for at least two of the three conventional serological tests, and non-cured patients (NCP), when parasitological, CS and CoML tests are all positive. This classification evaluates the presence of active infection (Galvão et al. 1993). CP and DP patients do not, therefore, present active infection, but patients included in the DP group continue to produce antibodies against $T$. cruzi antigens detected by CS (Galvão et al. 1993). A negative CoML predicts elimination of $T$. cruzi but this test has practical limitations, since it requires both live and infectious parasites.

CS tests are very useful in the diagnosis of chronic Chagas disease, but they are not suitable for monitoring the effectiveness of treatment of this infection because they have limitations when used as criteria for therapeutic cure. The CoML test, which detects lytic antibodies that are recognised by epitopes present on the surface of live trypomastigotes, has been used as an alternative method for determining whether the disease has been cured. In a 10-year follow-up study of 82 treated patients, only seven $(8.5 \%)$ would be considered cured on the basis of negative CS results, even though 21 (25.6\%) of them who consistently tested positive using CS, returned negative CoML results. These patients in whom there was a discrepancy between the results of CoML and CS have been described as dissociated and are considered cured (Galvão et al. 1993). However, CoML is not a routine test because it requires careful management of live infectious trypomastigotes, has many variables that are difficult to control and standardise (such as the live and motile parasite count) and requires human serum as a source of complement, which may vary from one donor to another. In addition, live target cells may be lysed by heterophylic antibodies (Levy et al. 1996). It should also be pointed out that heterologous strains can have different degrees of sensitivity (Jacobson et al. 1992). These facts may be responsible for the difficulties reported by some laboratories in relation to the reproducibility of CoML.

Negative CoML by itself is not a criterion for cure of Chagas disease because the absence of living trypomastigotes does not necessarily mean absence of active infection. The parasite may persist in tissues of the mammalian host in the amastigote form. Even circulating in the peripheral blood, these parasites would not stimulate the production of lytic antibodies, but could be the cause of a uniformly positive CS in the great majority of treated patients with a long history of Chagas disease (Cançado 1999). Furthermore, this author emphasises that the control of cure based on CS is important for a number of reasons: (i) parasitological tests (XD and $\mathrm{HC}$ ) have poor sensitivity, are slow and only available in research institutions; (ii) it is impossible for a negative CS test to occur with a positive parasitological test, except possibly in the case of immunosuppression; (iii) for the acute disease, CS is the universally accepted criterion for cure and (iv) all research into refined antigens, to be used for serological evaluation of chemotherapy, take patients consistently returning negative CS tests as the gold standard for cure. Positive CS conclusively demonstrates the presence of T. cruzi in the patient tissue, e.g., Chagas disease (Cançado 1999).

The reasons why CS remains positive for long periods are not clear, although a number of hypotheses have been put forward. Some have argued that mice infected with $T$. cruzi but parasitologically cured after specific chemotherapy continue to exhibit positive IIF tests 3-6 months after treatment as a result of parasite antigens being trapped by certain cells in the spleen (Andrade et al. 1991). Other studies have shown that a high proportion of antibodies detected by CS, in treated Chagas patients, are directed against the carbohydrate residue Gal $\alpha 1->3 \mathrm{Gal}$, a determinant also recognised by antibodies from noninfected healthy individuals (Gazzinelli et al. 1993). Due to their widespread distribution among microorganisms of the intestinal and pulmonary microflora, these determinants may continue to stimulate lymphocytes previously primed by $T$. cruzi Gala1->3 Gal epitopes, thereby accounting for false-positive results in CP. This fact suggests that the use of an antigen recognised by serum samples from the most chronically infected Chagas patients that do not express Gal 1 1->3 Gal residues might be useful in eliminating possible cross-reactive antibodies and hence false-positive reactions (Gazinelli et al. 1993).

A number of serological techniques have been evaluated as possible substitutes for the CoML test by using an ELISA with purified (Gazzinelli et al. 1993) and recombinant antigens (Krautz et al. 1995, Silva et al. 2002). Silva et al. (2002) showed that when the serum from patients previously investigated using parasitological and serological tests and classified as CP $(n=10)$, DP $(n=6)$ and NCP $(n=6)$ was assayed using the EIE-Rec kit, all the serum samples from NCPs tested positive and all the samples from CP tested negative. According to Silva et al. (2002), these results were fully consistent with those obtained previously using the classical tests. Two DPs displayed a positive reaction, while the other four had a negative reaction, similar to that observed in serum from individuals without Chagas disease. These four patients could therefore be considered $\mathrm{CP}$, suggesting that the EIE-Rec kit could be used to monitor the efficacy of Chagas disease treatment.

A new approach using flow cytometry to detect antilive trypomastigote antibodies and monitor the efficacy of specific treatments in human Chagas disease has been shown to be more sensitive and accurate than CoML (Martins-Filho et al. 1995, 2002). Recently, a flow cytometry approach used to detect anti-fixed epimastigote IgG antibodies (FC-AFEA-IgG) in serum from individuals infected with $T$. cruzi was evaluated in individuals classified into three distinct categories: not treated, treated but not cured and treated and cured. This demonstrates that FC-AFEA-IgG has an extraordinary capacity as a serological criterion for assessing cure after Chagas disease treatment (Vitelli-Avelar et al. 2007). These results represent a great advance in the use of serological techniques for clinical investigation of Chagas disease and they clearly indicate new ways forward. Although this method requires an expensive flow cytometer that 
is not yet available in many laboratories, flow cytometry could be seen in the near future as a way of assessing cure in treated Chagas patients.

On the other hand, several groups have attempted to develop more sensitive assays using molecular approaches. PCR has been introduced to detect T. cruzi in blood samples from Chagas patients (Moser et al. 1989, Sturm et al. 1989, Avila et al. 1991, 1993, Britto et al. 1993, Wincker et al. 1994, Junqueira et al. 1996, Kirchhoff et al. 1996, Gomes et al. 1998, Castro et al. 2002) and also used to monitor treatment outcomes in both the acute and chronic phases of Chagas disease (Britto et al. 1995, 2001, Russomando et al. 1998, Braga et al. 2000, Lauria-Pires et al. 2000, Solari et al. 2001, Galvão et al. 2003, Schijman et al. 2003, Zulantay et al. 2004, Sanchez et al. 2005). These studies confirmed the usefulness of PCR strategies as a clinical tool for early detection of treatment failure. The sensitivity of PCR for $T$. cruzi detection, when compared with traditional parasitological methods, demonstrates its potential use for evaluating chemotherapeutic efficacy.

According to Galvão et al. (2003), there is no guarantee that a single negative PCR signifies parasitological cure, especially since it is well known that parasitaemia occurs in waves during the long course of Chagas disease. This fact reinforces the principle that the value of parasitological tests lies mainly in the positive results they yield; a positive PCR in blood may reflect treatment failure. In this respect, PCR can be used as an early marker of resistance to specific chemotherapy years before a conclusion can be drawn from serological analysis. When serology and PCR both present negative results this is probably an indication that a cure has taken place (Russomando et al. 1998).

Nevertheless, it should be pointed out that PCR is currently an "in house" method, subject to the same shortcomings observed with CS in 1970, when there was no perfect agreement among different laboratories. Once kits started to be produced on an industrial basis, to the same quality standards, results from different laboratories could be compared and CS is now reliable. A recent TDR/WHO-sponsored meeting in Buenos Aires was held to overcome this lack of standardisation and guidelines are now available (TDR 2009). This represents a first step towards obtaining reliable and comparable results, but much more needs to be done before interested industries start to produce commercial kits. In the meantime, positive results obtained in routine labs in a treated patient should be viewed with caution, since false positives have been observed in some $\mathrm{CP}$ with serious negative consequences for these patients.

Even with major advances in serological diagnosis of the chronic phase, the acute phase cannot be properly evaluated using serological tests, mainly because there are no available kits for IgM detection in cases of Chagas disease. One of the difficulties is that of obtaining positive samples, mainly in countries where acute cases are no longer reported (MS 2005). The "in house" IIF with anti-IgM conjugate may be employed in those cases where diagnosis is suspected but has not been parasitologically confirmed. The MS also recommends the in- troduction of serological diagnostic testing for Chagas disease in pregnant women. Molecular testing using PCR combined with hybridization have shown promising results and may be used as a confirmatory test (MS 2005). There is, however, a need for other tests to identify CP soon after specific treatment, for a prognosis marker (Verçosa et al. 2007, Lorena et al. 2008) and for prediction of congenital transmission.

\section{REFERENCES}

Affranchino JL, Ibanez CF, Luquetti AO, Rassi A, Reyes MB, Macina RA, Aslund L, Petterson U, Frasch ACC 1989. Identification of a Trypanosoma cruzi antigen that is shed during the acute phase of Chagas' disease. Mol Biochem Parasitol 34: 221-228.

Almeida E, Krieger MA, Carvalho MR, Oelemann W, Goldenberg S 1990. Use of recombinant antigens for the diagnosis of Chagas' disease and blood bank screening. Mem Inst Oswaldo Cruz 85: 513-517.

Almeida JO, Fife EH Jr 1976. Quantitatively standardized comple ment-fixation methods for critical evaluation of antigens prepared from Trypanosoma cruzi. Pan Am Health Org 39, 86 pp.

Avila HA, Borges-Pereira J, Thiemann O, de Paiva E, Degrave W, Morel CM, Simpson L 1993. Detection of Trypanosoma cruzi in blood specimens of chronic chagasic patients by polymerase chain reaction amplification of kinetoplast minicircle DNA: comparison with serology and xenodiagnosis. J Clin Microbiol 31: 2421-2426.

Avila HA, Sigman DS, Cohen LM, Millikan RC, Simpson L 1991. Polymerase chain reaction amplification of Trypanosoma cruzi kinetoplast minicircle DNA isolated from whole blood lysates: diagnosis of chronic Chagas disease. Mol Biochem Parasitol 48: 211-222.

Andrade SG, Freitas LAR, Peyrol S, Pimentel AR, Sadigursky M 1991. Experimental chemotherapy of Trypanosoma cruzi infection: persistence of parasite antigens and positive serology in parasitologically cured mice. Bull World Health Organ 69: 191-197.

Braga MS, Lauria-Pires L, Arganaraz ER, Nascimento RJ, Teixeira AR 2000. Persistent infections in chronic Chagas' disease patients treated with anti-Trypanosoma cruzi nitroderivatives. Rev Inst Med Trop São Paulo 42: 157-161.

Britto C, Cardoso MA, Vanni CMM, Haslocher-Moreno A, Xavier SS, Wincker P 1995. Polymerase chain reaction detection of Trypanosoma cruzi in human blood samples as a tool for diagnosis and treatment evaluation. Parasitology 110: 241-247.

Britto C, Cardoso MA, Wincker P, Morel CM 1993. A simple protocol for the physical cleavage of Trypanosoma cruzi kinetoplast DNA present in blood samples and its use in polymerase chain reaction (PCR)-based diagnosis of chronic Chagas disease. Mem Inst Oswaldo Cruz 88: 171-172.

Britto C, Silveira C, Cardoso MA, Marques P, Luquetti A, Macedo V, Fernandes O 2001. Parasite persistence in treated chagasic patients revealed by xenodiagnosis and polymerase chain reaction. Mem Inst Oswaldo Cruz 96: 823-826.

Brumpt 1914. Le xénodiagnostic. Applicationau diagnostic de quelques infections parasitaires et en particulier a la trypanosomose de chagas. Bull Soc Pat Exot 7: 706-710.

Camargo ME 1966. Fluorescent antibody test for the serodiagnosis of American trypanosomiasis. Technical modification employing preserved culture forms os Trypanosoma cruzi in a slide test. Tev Inst Med Trop São Paulo 8: 227-235.

Cançado JR 1999. Criteria of Chagas disease cure. Mem Inst Oswaldo Cruz 94: 331-335.

Carvalho MR, Krieger MA, Almeida E, Oelemann W, Shikanai-Yassuda AA, Ferreira AW, Pereira JB, Sáez-Alquézar A, Dorlhiac- 
Llacer PE, Chamone DF, Goldenberg S 1993. Chagas' disease diagnosis: evaluation of several tests in blood bank screening. Transfusion 33: 830-834.

Castro AM, Luquetti AO, Rassi A, Rassi GG, Chiari E, Galvão LMC 2002. Blood culture and polymerase chain reaction for the diagnosis of the chronic phase of human infection with Trypanosoma cruzi. Parasitol Res 88: 894-900.

Cerisola JA, Fatala Chaben M, Lazaari JO 1962. Hemagglutination test for the diagnosis of Chagas' disease. Prensa Med Argent 24: 1761-1767.

Chagas, CRJ 1909. Nova tripanozomiaze humana: estudos sobre a morfolojia e o ciclo evolutivo do Schizotrypanum cruzi n. gen., n. sp., ajente etiolojico de nova entidade morbida do homem. Mem Inst Oswaldo Cruz 1: 159-218.

Chiari E, Brenner Z 1966. Contribuição ao diagnóstico parasitológico da doença de Chagas na sua fase crônica. Rev Inst Med Trop São Paulo 8: 134-138.

Cummings KL, Tarleton RL 2003. Rapid quantitation of Trypanosoma cruzi in host tissue by real-time PCR. Mol Biochem Parasitol 129: 53-59.

Duffy T, Bisio M, Altcheh J, Burgos JM, Diez M, Levin MJ, Favaloro RR, Freilij H, Schijman AG 2009. Accurate real-time PCR strategy for monitoring bloodstream parasitic loads in Chagas disease patients. PLoS Negl Trop Dis 3: e419.

Franco da Silveira FJ, Umezawa ES, Luquetti AO 2001. Chagas' disease: recombinant Trypanosoma cruzi antigens for serological diagnosis. Trends Parasitol 17: 286-291.

Gadelha AAM, Verçosa AFA, Lorena VMB, Nakazawa M, Carvalho AB, Souza WV, Ferreira AGP, Silva ED, Krieger MA, Goldenberg S, Gomes YM 2003. Chagas' disease diagnosis: comparative analysis of recombinant ELISA with conventional ELISA and hemagglutination test. Vox Sanguinis 85: 165-170.

Galvão LMC, Chiari E, Macedo AM, Luquetti AO, Silva SA, Andrade AL 2003. PCR assay for monitoring Trypanosoma cruzi parasitemia in childhood after specific chemotherapy. J Clin Microbiol 41: 5066-5070.

Galvão LMC, Nunes RMB, Cançado JR, Brener Z, Kretli AU 1993. Lytic antibody titer as a means of assessing cure after treatment of Chagas disease: a ten years follow up study. Trans $R$ Soc Trop Med Hyg 87: 220-223.

Gazzinelli RT, Galvão LMC, Krautz GM, Lima APCA, Scharfstein J, Krettli AU 1993. Use of Trypanosoma cruzi purified glycoprotein (GP57/51) or trypomastigote shed antigens to gauge cure in human Chagas' disease. Am J Trop Med Hyg 49: 625-635.

Goldenberg S, Krieger MA, Lafaille JJ, Almeida E, Oelemann W 1991. Use of Trypanosoma cruzi antigens in the immunological diagnosis of Chagas' disease. Mem Inst Butantan 53: 71-76.

Gomes ML, Galvão LM, Macedo AM, Pena SD, Chiari E 1999. Chagas disease diagnosis: comparative analysis of parasitologic, molecular and serologic methods. Am J Trop Med Hyg 60: 205-210.

Gomes ML, Macedo AM, Vago AR, Pena SD, Galvão LM, Chiari E 1998. Trypanosoma cruzi: optimization of polymerase chain reaction for detection in human blood. Exp Parasitol 88: 28-33.

Gomes YM 1997. PCR and sero-diagnosis in chronic Chagas' disease: biotechnological advances. Appl Biochem Biotechnol 66: 107-119.

Gomes YM, Pereira VRA, Nakazawa M, Rosa DS, Barros MNDS, Ferreira AGP, Silva ED, Ogatta SF, Krieger MA, Goldenberg S 2001. Serodiagnosis of chronic Chagas' disease by using EIERecombinante-Chagas-Biomanguinhos kit. Mem Inst Oswaldo Cruz 96: 497-501.
Guerreiro C, Machado A 1913. Da reação de Bordet e Gengou na moléstia de Carlos Chagas como elemento diagnóstico. Brasil Med 27: 225-226.

Jacobson KC, Fletcher RC, Kuhn RE 1992. Binding of antibody and resistance to lysis of Trypanosoma cruzi. Parasitol Immunol 14: 1-12.

Junqueira ACV, Chiari E, Wincker P 1996. Comparison of the polymerase chain reaction with two classical parasitological methods for the diagnosis of Chagas disease in endemic region of NorthEastern Brazil. Trans R Soc Trop Med Hyg 90: 129-132.

Kirchhoff LV, Votava JR, Ochs DE, Moser DR 1996. Comparison of PCR and microscopic methods for detecting Trypanosoma cruzi. J Clin Microbiol 34: 1171-1175.

Krautz GM, Galvão LMC, Cançado JR, Guevara-Espinoza A, Ouaissi A, Krettli AU 1995. Use of a 24-kilodalton Trypanosoma cruzi recombinant protein to monitor cure of human Chagas' disease. J Clin Microbiol 33: 2086-2090.

Krettli AU, Brener Z 1982. Resistance against Trypanosoma cruzi associated to anti-living trypomastigotes antibodies. J Immunol 28: 2009-2012.

Krieger MA, Almeida E, Oelemann W, Lafaille JJ, Pereira JB, Carvalho MR, Goldenberg S 1992. Use of recombinant antigens for the accurate immunodiagnosis of Chagas'disease. Am J Trop Med Hyg 46: 427-434.

Lafaille JJ, Linss J, Krieger MA, Souto-Padron T, de Souza W, Goldenberg S 1989. Structure and expression of two Trypanosoma cruzi genes encoding antigenic proteins bearing repetitive epitopes. Mol Biochem Parasitol 35:127-136.

Lauria-Pires L, Braga MS, Vexenat AC, Nitz N, Simões-Barbosa A, Tinoco DL, Teixeira AR 2000. Progressive chronic Chagas heart disease ten years after treatment with anti-Trypanosoma cruzi nitroderivatives. Am J Trop Med Hyg 63: 111-118.

Levin MJ, Franco da Silveira J, Frasch ACC, Camargo ME, Lafon S, Degrave WM, Rangel-Aldao R 1991. Recombinant Trypanosoma cruzi antigens and Chagas' disease diagnosis: analysis of a workshop. FEMS Microbiol Immunol 89: 11-20.

Levy AMA, Boainain E, Kloetzel JK 1996. In situ indirect fluorescent antibody: a new specific test to detect ongoing chagasic infections. J Clin Lab Analysis 10: 98-103.

Lorena VMB, Verçosa AFA, Machado RCA, Cavalcanti MGAM, Silva ED, Ferreira AGP, Correa-Oliveira R, Pereira VRA, Gomes YM. 2008. Cellular immune response from chagasic patients to CRA or FRA recombinant antigens to Trypanosoma cruzi.J Clin Lab Anal 22: 91-98.

Luquetti AO 1999. Evolution of knowledge on the etiological diagnosis of chagasic infection. Mem Inst Oswaldo Cruz 94 (Suppl. I): $283-284$.

Luquetti AO, Rassi A 2000. Diagnóstico laboratorial da infecção pelo Trypanosoma cruzi. In Z Brener, Z Andrade, M Barral-Netto (org.), Trypanosoma cruzi e Doença de Chagas, Editora Guanabara Koogan, Rio de Janeiro, pp. 344-348.

Martins-Filho AO, Pereira MES, Carvalho JF, Cançado JR, Brener Z 1995. Flow cytometry, a new approach to detect anti-live trypomastigote antibodies and monitor the efficacy of specific treatment in human Chagas'disease. Clin Diag Lab Immunol 2: 569-573.

Martins-Filho AO, Santos SMEC, Teixeira A, Correa-Oliveira R, Rassi A, Luquetti AO, Rassi GG, Brener Z 2002. Double-blind study to evaluate flow cytometry analysis of anti-live trypomastigote antibodies for monitoring treatment efficacy in cases of human Chagas' disease. Clin Diag Lab Immunol 9: 1107-1113.

Matsumoto TK, Cotrim PC, Franco da Silveira J, Stolf AMS, Umezawa ES 2002. Trypanosoma cruzi: isolation of a immunodominant 
peptide of TESA (trypomastigote excreted-secreted antigens) by gene cloning. Diag Microbiol Infec Dis 39: 169-176.

Moncayo A, Luquetti AO 1990. Multicentre double blind study for evaluation of Trypanosoma cruzi defined antigens as diagnostic reagents. Mem Inst Oswaldo Cruz 85: 489-495.

Moser DR, Kirchoff LV, Donelson JE 1989. Detection of Trypanosoma cruzi by DNA amplification using the polymerase chain reaction. J Clin Microbiol 27: 1477-1482.

MS - Ministério da Saúde 2005. Consenso Brasileiro em Doença de Chagas. Rev Soc Bras Med Trop 30 (Suppl. III): 12-14.

Nakazawa M, Rosa DS, Pereira VRA, Moura MO, Furtado VC, Souza WV, Barros MNDS, Abath FGC, Gomes YM 2001. Excretorysecretory antigens of Trypanosoma cruzi are potentially useful for serodiagnosis of chronic Chagas' disease. Clin Diag Lab Anal 8: 1024-1027.

Paranhos GS, Cotrin PC, Mortara RA, Rassi A, Corral R, Freilij HL, Grinstein S, Wanderley J, Camargo ME, Franco da Silveira J 1990. Trypanosoma cruzi: cloning and expression of an antigen recognized by acute and chronic human chagasic sera. Exp Parasitol 71: 284-293.

Piron M, Fisa R, Casamitjana N, López-Chejade P, Puig L, Vergés M, Gascón J, Gómez, Prat J, Portús M, Sauleda S 2007. Development of a real-time PCR assay for Trypanosoma cruzi detection in blood samples. Acta Trop 103: 195-200.

Roddy P, Goiri J, Flevaud L, Palma PP, Morote S, Lima N, Villa L, Torrico F, Albajar-Viñas P 2008. Field evaluation of a rapid immunochromatographic assay for Trypanosoma cruzi infection using whole blood in Sucre, Bolívia. J Clin Microbiol 46: 2022-2027.

Russomando G, de Tomassone MM, de Guillen I, Acosta N, Vera N, Almiron M, Candia N, Calcena MF, Figueredo A 1998. Treatment of congenital Chagas' disease diagnosed and followed up by the polymerase chain reaction. Am J Trop Med Hyg 59: 487-491.

Sanchez G, Coronado X, Zulantay I, Apt W, Gajardo M, Solari S, Venegas J 2005. Monitoring the efficacy of specific treatment in chronic Chagas disease by polymerase chain reaction and flow cytometry analysis. Parasite 12: 353-357.

Schijman AG, Altcheh J, Burgos JM, Biancardi M, Bisio M, Levin MJ, Freilij H 2003. Aetiological treatment of congenital Chagas' disease diagnosed and monitored by the polymerase chain reaction. J Antimicrob Chemother 52: 441-449.

Schmunis GA 1991. Trypanosoma cruzi, the etiological agent of Chagas' disease: status in the blood supply in endemic and non endemic countries. Transfusion 31: 547-557.

Schmunis GA 2007. Epidemiology of Chagas disease in non-endemic countries: the role of international migration. Mem Inst Oswaldo Cruz 102 (Suppl. I): 75-85.

Silva ED, Pereira VRA, Lorena VMB, Nakazawa M, Ferreira AGP, Krieger MA, Goldenberg S, Correa-Oliveira R, Gomes YM 2002. Use of EIE-Recombinante-Chagas-Biomanguinhos kit to monitoring Chagas' disease. J Clin Lab Anal 16: 132-136.

Solari A, Ortíz S, Soto A, Arancibia C, Campillay R, Contreras M, Salinas P, Rojas A, Schenone H 2001. Treatment of Trypanosoma cruzi-infected children with nifurtimox: a 3 year follow-up by PCR. J Antimicrob Chemother 48: 515-519.

Souza FF, Castro-E-Silva O, Marin-Neto JA, Sankarankutty AK, Teixeira AC, Martinelli AL, Gaspar GG, Melo L, Figueiredo JF, Romano MM, Maciel BC, Passos AD, Rossi MA 2008. Acute chagasic myocardiopathy after orthotopic liver transplantation with donor and recipient serologically negative for Trypanosoma cruzi: a case report. Transplant Proc 40: 875-878.
Stolf MAS 1992. Trypanosoma cruzi antigen in serodiagnosis. In S Wendel, Z Brener, ME Camargo, A Rassi (eds.), Chagas' disease (American trypanosomiasis): its impact on transfusion and clinical medicine, ISBT Brazil'92, São Paulo, p. 195-205.

Sturn NR, Degrave W, Morel C, Simpson L 1989. Sensitive detection and schizodeme classification of Trypanosoma cruzi cells by amplification of kinetoplst minicircle DNA sequences: use in diagnosis of Chagas disease. Mol Biochem Parasitol 33: 205-214.

TDR 2009. Standardized protocol for PCR analysis of Chagas disease. [homepage on the internet]. Available from http://apps.who. int/tdr/svc/publications/tdrnews/issue-82/meeting.

Umezawa E, Nascimento MS, Stolf AMS 2001. Enzyme-linked immunosorbent assay with Trypanosoma cruzi excreted-secreted antigens (TESA-ELISA) for serodiagnosis of acute and chronic Chagas' disease. Diag Microbiol Infec Dis 39: 169-176.

Umezawa ES, Bastos S, Camargo ME, Yamauchi LM, Santos MR, Gonzalez A, Zingales B, Levin MJ, Souza O, Rangel-Aldao R, Silveira JF 1999. Evaluation of recombinant antigens for serodiagnosis of Chagas' disease in South and Central. Am J Clin Microbiol 37: 1554-1560.

Umezawa ES, Nascimento MS, Kersper N Jr, Coura JR, BorgesPereira J, Junqueira ACV, Camargo ME 1996. Immunoblot assay using excreted-secreted antigens of Trypanosoma cruzi in serodiagnosis of congenital, acute and chronic Chagas' disease. J Clin Microbiol 34: 2143-2147.

Verani JR, Seitz A, Gilman RH, LaFuente C, Galdos-Cardenas G, Kawai V, de LaFuente E, Ferrufino L, Bowman NM, PinedoCancino V, Levy MZ, Steurer F, Todd CW, Kirchhoff LV, Cabrera L, Verastegui M, Bern C 2009. Geographic variation in the sensitivity of recombinant antigen-based rapid tests for chronic Trypanosoma cruzi infection. Am J Trop Med Hyg 80: 410-415.

Verçosa AFA, Lorena VMB, Melo MFAD, Cavalcanti MGA, Ferreira AGP, Silva ED, Souza WV, Gomes YM 2007. Chagas' disease: IgG isotypes against cytoplasmic (CRA) and flagellar (FRA) recombinant repetitive antigens of Trypanosoma cruzi in chronic chagasic patients. J Clin Lab Anal 21: 271-276.

Virreira M, Alonso-Vega C, Solano M, Jijena J, Brutus L, Bustamante Z, Truyens C, Schneider D, Torrico F, Carlier Y, Svoboda M 2006. Congenital Chagas disease in Bolivia is not associated with DNA polymorphism of Trypanosoma cruzi. Am J Trop Med Hyg 75: 871-879.

Vitelli-Avelar DM, Sather-Avelar R, Wendling APB, Rocha RDR, Carvalho AT, Martins NE, Dias JCP, Rassi A, Luquetti A, Elói-Santos SM, Martins-Filho OA 2007. Non-conventional flow cytometry approaches to detect anti-Trypanosoma cruzi immunoglobulin G in the clinical laboratory. J Immunol Meth 318: 102-112.

Voller A, Draper C, Bidwell DE, Bartlett AA 1975. Microplate enzyme-linked immunosorbent assay (ELISA) for Chagas' disease. Lancet 1: 426-429.

WHO - World Health Organization 1991. Control of Chagas' disease, Technical Report Series 811, Geneva, 95 pp.

Winker P, Britto C, Borges Pereira J, Cardoso MA, Oelemann W, Morel CM 1994. Use of simplified polymerase chain reaction procedure to detect Trypanosoma cruzi in blood samples from chronic chagasic patients in a rural endemic area. Am J Trop Med Hyg 51: 771-777.

Zingales BA, Gruber A, Ramalho CB, Umezawa ES, Colli W 1990. Use of recombinant proteins of Trypanosoma cruzi in the serological diagnosis of Chagas disease. Mem Inst Osvaldo Cruz 85: 519-522.

Zulantay I, Honores P, Solari A, Apt W, Ortiz S, Osuna A, Rojas A, López B, Sánchez G 2004. Use of polymerase chain reaction (PCR) and hybridization assays to detect Trypanosoma cruzi in chronic chagasic patients treated with itraconazole or allopurinol. Diag Microbiol Infect Dis 48: 253-257. 